\title{
The office of prophets as an emergency measure
}

\begin{abstract}
Author:
Joseph J. de Bruyn ${ }^{1}$

Affiliation:

${ }^{1}$ Faculty of Theology, North-

West University, South Africa

Correspondence to:

Joseph de Bruyn

Email:

jjdebruyn@ymail.com

Postal address:

Private Bag X1288,

Potchefstroom 2520,

South Africa

Dates:

Received: 05 Nov. 2012

Accepted: 09 Sept. 2013

Published: 29 Oct. 2013

How to cite this article: De Bruyn, J., 2013, 'The office of prophets as an emergency measure', In die Skriflig/In Luce Verbi 47(1), Art. \#673, 7 pages. http:// dx.doi.org/10.4102/ids. v47i1.673
\end{abstract}

\section{Copyright:}

(C) 2013. The Authors.

Licensee: AOSIS OpenJournals. This work

is licensed under the Creative Commons

Attribution License.
Read online:

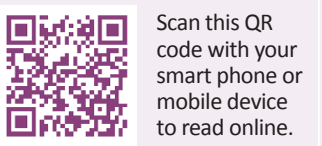

Initially there was not supposed to be a prophetic office in Israel. 'Prophetism' was considered to be part of work that the priests performed. Thus, the priests were seen to be acting as prophets. Generally speaking, the prophets of the Old Testament are described as people who preached the Word of God. In the same way, priests are generally described as people who fulfilled functions at the temple and whose task it was to sacrifice on behalf of the Israelites. This article, however, argues that Yahweh intended much more through the establishment and ministry of the priests than merely administer sacrifices. It is the contention that Yahweh ordained the office of priests to preach the Word of God or to give advice in accordance with the will of Yahweh as it is documented in the Torah. The article's contribution to the subject of prophetism in Israel will begin by studying the chronological history of Israel as it is described in the Hebrew Bible. The terms prophet, prophecy and prophetism will also be examined as they are used in the Hebrew Bible. By doing so, the article will show that it was only when the priests failed in their prophetic calling or when Yahweh wanted to change the cult or political establishment that He called people from outside of the established cult to fulfil the role of prophet. Yahweh used the prophetic office in times of need. One may call it an emergency measure - in times when the priests failed in their calling.

Die amp van profeet as 'n noodmaatreël. Die bedoeling was aanvanklik nie dat daar 'n profetiese amp in Israel moes wees nie. 'Profetisme' was veronderstel om deel van die priesterlike amp te wees. Die priesters het dus as profete opgetree. Oor die algemeen word die Ou-Testamentiese profete as persone beskryf wat die Woord van God verkondig het. Op 'n soortgelyke algemene wyse word priesters as persone beskryf wat hulle werk by die tempel verrig het en wie se taak dit was om namens die Israeliete te offer. Hierdie artikel argumenteer egter dat Jahwe oorspronklik met die instelling van die priesteramp meer as net offerdiens in gedagte gehad het. Jahwe het oorspronklik die priesteramp ingestel om die Woord van God te preek en om advies te gee in oorstemming met die wil van Jahwe soos dit in die Tora vervat is. In hierdie artikel word die chronologiese geskiedenis van Israel soos dit in die Hebreeuse Bybel beskryf word, bestudeer. Die terme profeet, profesie en profetisme soos in die Hebreeuse Bybel gebruik, sal ook beskryf word. In die bestudering van hiervan sal aangedui word dat Jahwe persone van buite die kultus slegs as profete aangestel het wanneer die priesters in hulle profetiese taak gefaal het of wanneer Hy verandering in die bestaande kultus of politieke stelsel te weeg wou bring. Jahwe het dus die profete-amp as noodmaatreël gebruik wanneer die priesters in hulle profetiese roeping gefaal het.

\section{Introduction}

From recently acquired knowledge (De Villiers 2010: 359-364; Nissinen 2010:4-6; Sakenfeld 2008:625), we may conclude that the function of the prophets formed an integral part of the culture of all the nations from the Ancient Near East (ANE). Prophets often played a pivotal role in Old Testament (OT) narratives (at least according to Israelite history). Some of the books of the Bible are named after a prophet whilst a significant part of the OT canon is called nébî $̂$ $m$ [prophets]. It is natural then to expect the Hebrew Bible to inform us about the origins of the prophets in the same way that it recounts the establishment of the office of priest or king. Yet the Hebrew Bible does not convey this information. Instead, it narrates how Yahweh himself established the priests and the kings in their respective offices (cf. Ex 28-29, 39; Nm 4, 6:19-23; 8, 17; 1 Sm 8-10).

The offices of priest and king had their unique role in which they acted as mediators of Yahweh's will in society. The priests mediated the will of Yahweh through their preaching and teaching and through the cult as a whole. The king was the anointed one of Yahweh who ruled the nation on behalf of God. Therefore, the questions arises: Why does the Old Testament not mention the establishment of a prophetic office in the Old Testament? Why did God call prophets to preach 
and to reveal his will? Did the priests and the cult provide insufficient means to reveal God's will and to preach his Word? To make the question even more problematic, we seldom read about prophets praising the priests. On the contrary, prophets usually criticised the priests, that is the cult or the king. Throughout the OT narratives in which priests perform Yahweh's will or work, prophets are absent (cf. $2 \mathrm{Ki}$ 11-12; 22 Ki 15:1-6; Chr 23-24; 2 Chr 26; the work of Ezra as described in Ezra and Nehemiah). ${ }^{1}$ This article found that part of the priests' original ministry was to fulfil a prophetic role in Israel by preaching and revealing or interpreting the Word and will of Yahweh. Naturally this finding will be based on a broader understanding of the definition of 'prophetism' contrary to scholars who previously drew a sharp distinction between 'prophetism' and 'divination' (Carroll 1969:401; De Villiers 2010:359-364; Thompson 1974:212-213). I prefer to focus on the common goal of 'prophetism' and 'divination', namely to reveal the will of Yahweh. Also, both 'forms' of revelation is initiated in the divine realm (Walton 2006:240, 249). This article would therefore rather focus on the function of divination in society than differentiate between so-called forms of divination or prophecy. It is in this regard that it will be indicated that the work of the priest fits the general definition of 'prophetism' and 'prophecy'.

\section{Definitions}

Presently, religious leaders and members of the church often use the terms prophet, prophecy and prophetism to help believers understand their role and task in the modern world. In this way, Christians are encouraged to spread the Word of God, not only through missionary work, but more importantly by 'preaching' the Word of God through their lifestyle of influencing the world around them positively. Under the influence of John Calvin, some reformed churches use the term prophet to define the role and work of the minister (Calvyn 1992:1321). Despite the frequent use of these terms, theologians will not agree upon only one definition of 'prophet', 'prophecy' and 'prophetism'. For example, the way in which the writers of the OT apply and understand these terms differs from the way in which scholars in the New Testament or church dogma will understand by 'prophet', 'prophecy' and 'prophetism' (De Villiers 2010:359-564).

For the purpose of this article, the origin of the word prophet in its general sense will be used as a starting point. The English word appears to have been derived from the Greek word prophètès ( $\pi \rho \circ \varphi \eta \tau \eta \varsigma)$. The Hebrew word for 'prophet' in the OT is $n \bar{a} b \bar{\imath}$ (נְָבְיא) (cf. De Villiers 2010:1). In accordance with the monotheistic religion of Israel, we can then define a 'prophet' as a human medium acting between the God of Israel and his people. Therefore, a 'prophet' is a person who transmits messages from God, and by doing so, reveals the will and plans of God to the community (cf. De Villiers 2010:359-654; Freedman 2000:1086-1088; Nissinen 2004:18-19). Prophets conveyed God's opinion, reactions, intentions and his very words to God's people. Prophets were to give guidance to 1.This fact will be discussed later in the article.
Israel. In addition, the 'prophet' sometimes interpreted events in the light of, or as part of a larger picture as it was planned and orchestrated by Yahweh (e.g. the historical narrative of Daniel). To be a prophet means having a divine calling to speak on behalf of Yahweh. This is a calling to be the mouthpiece of God (Hill \& Walton 2009:503; Lundbom 2010:9; Waltke 2007:805).

From the above definition of 'prophet', we can deduce that 'prophetism' in general refers to the act of communicating the Word of God with the purpose of influencing the cult and or political life of Israel. Through prophetism, the invisible God becomes audible (Waltke 2007:805). Prophetism in general was aimed at guiding the decision-making of the king or ordinary citizens by warning them or advising them according to the will of Yahweh and by applying the tôrâ (cf. Nissinen 2010:15-16; Baker 1999:270; Hill \& Walton 2009:503). The term נָביא does not include the functions of all the other different persons who practised prophetism (Freedman 2000:1086-1088; Hill \& Walton 2009:503; Sakenfeld 2008:623). Other terms for 'prophet' are חוֹזָ [seer] (2 Sm 24:11; Am 7:12) and מַלְאָּ [messenger].

In the past, some scholars (Carroll 1969:401; Driver 1902:227; Kraus 1966:108-109; Nicholson 1967:77; Thompson 1974:212213) were of the opinion that the prophetic office was a permanent institution in Israel. This implies that Israel had an office of prophets similar to the office of priest and king. Although we know today that prophets and prophetism formed part of the cultures of all the peoples of the ANE, there is not enough evidence in the OT to support the notion of the institution of a permanent office of prophets - like those that the priests and kings occupied in Israel (cf. Lamb 2010:172173). On the contrary, the OT's narration does not testify that Yahweh instituted a permanent prophetic office as in the case of the priests and kings. Instead, the history of Israel have accounts of occasions where prophets are not mentioned at all - even though one could argue that prophetism still may have occurred during that time (cf. 2 Ki 11-12; 2 Ki 15:1-6; 2 Chr 23-24; 2 Chr 26; the work of Ezra as described in Ezra and Nehemiah).

In these cases, as it will be indicated later in the article, we do not encounter a prophet conducting prophetism, but an established priest or priests fulfilling a prophetic role. Therefore, we should avoid the misconception that prophetism is executed by a prophetic office or that prophetism is always the task of a prophet. I even go further by arguing that Yahweh intended the established cult priests, and not the prophets through a separate office, to perform prophetism.

\section{Forms of prophetism - priests and prophets}

In the past, scholars drew a distinction between 'prophecy' and 'divination' (Carroll 1969:401; De Villiers 2010:359-364; Driver 1902:227; Kraus 1966:108-109; Nicholson 1967:77; Thompson 1974:212-213). Prophecy was described as a non- 
inductive or an inspired form of divination (Walton 2006:240). This means that the diviner does not employ any special techniques to receive a message from the $\operatorname{deity}(\mathrm{s})$ as was the case with inductive divination. With inductive divination, a person could use a range of techniques like astrology, pouring oil on water, slaughtering animals, studying the stars or the movement of clouds or using drugs ${ }^{2}$ (Walton 2006:248). This form of divination requires 'specialised knowledge' and therefore 'special training'. It is important to note that inductive divination was no less initiated from the divine realm (Yahweh) than non-inductive divination (prophecy) (Walton 2006:249). Inductive divination almost always formed part of the practices of established cult(s). In the cultic environment of Israel, the people who conducted inductive divination were priests. They were 'academics' and were therefore experts in their field. In the ANE, these educated academics mostly stemmed from selected families. In Israel, they originated from the tribe of Levi (cf. Ex 29:1; Lv 8; Nm 4).

Not all forms of inductive divination were practiced in Israel (cf. Dt 18:9-13). Nevertheless, we know that it formed part of the cults of Israel and Judah. The best examples of such divination are the priestly use of the urim and tummim ${ }^{3}$ (cf. Lv 2:63; Ezr 27:21) or the ephod ${ }^{4}$ (1 Sm 2:28, 23:9). In Israel, as was the case in the rest of the ANE, the cult priests practised the various forms of inductive divination. At the temple, the priests were educated in the arts and skills of divination. In Israel, the Levites under the leadership of the Aaronite high priests were called and established by Yahweh to reveal his will through their actions within the temple cult. Furthermore, Yahweh chose the priests to reveal the will of God by teaching the Israelites (cf. Lv 10:11; Dt 33:10; Neh 8; Ml 2:7; Van Groningen 1990:35). As teachers, the priests were messengers - prophets - of Yahweh (cf. Ml 2:7). The priests spoke to Yahweh on behalf of other people (cf. Jdg 18:5) and they sometimes prophesied by employing visions (Is 28:7).

During the Second Temple Period, priests developed another form of inductive divination. During this period in history, priestly scribes (for example Ezra) ${ }^{5}$ started to write and then compiled earlier records of Israel's history and traditions. The written records of the words and work of prophets were also collected. The priests started to interpret and reinterpret these written records as part of their function as revealers of God's will. Thus, in this period, God's words and will were not transmitted orally, but in literary form (Nissinen 2010:18-19). In this sense, prophetism became literary inclined. Therefore, as artificial the way in which Waltke (cf. 2007:807) reduces the work of the priest as 'not having the word of God', but his catechism would be questioned. It is believed that, on the basis of Exodus 19:5-6, it can be argued that God originally intended to establish his kingdom through Israel as a nation. In this process of establishing his kingdom on 2.As in the case of the Oracle of Delphi.

3.Divining stones uses by priests (Freedman 2000:1349; Kitz 2000:207-214).

4.A non-iconic vestment employed in obtaining oracles (Freedman 2000:415).

5.Cf. Nehemia 8:1-2 where Ezra is called a scribe as well as a priest. earth, the priests were the ones who were supposed to take the lead, not the prophets. The priests were supposed to have received the 'word of God' as much as the later prophets did.

From the above, it can be concluded that priests were supposed to prophesy the will of Yahweh to all Israel. This implies that they were to guide the decision-making of the king or ordinary citizens by warning them or simply giving advice in accordance with the will of Yahweh. Priests prophesied in the following ways:

- teaching the law of Moses to the people;

- writing down the history of Israel and the oral traditions of prophetism;

- compiling written traditions;

- interpreting and reinterpreting the law and written traditions;

- acting as mediators between Yahweh and the people (Sakenfeld 2008:598-599) through the (temple-)cult as a whole (Murphy 2002:34-35; Nissinen 2010:18-19).

In the religious experience of the ANE, the temple can be described as the sphere of intersection between heaven and earth (De Villiers 2010:259-364). The temple was the area where humans and deities met and communicated. Inside the temple, the gods disclosed their will and revealed ethereal knowledge by means of their prophets. In Israel, the temple of Yahweh was viewed in much the same way. According to biblical testimony Yahweh appointed the priests to act as mediators between himself and the people at the temple. Therefore, in Israel the priests were actually ordained to conduct prophetism (fulfil the role of prophet) too.

Non-inductive divination (prophecy) was almost solely performed under the influence of the Spirit of the Lord. No 'special knowledge' or 'training' were needed - only a divine calling (e.g. in the case of Amos; Lundbom 2010:9-12). Prophets usually conducted this form of divination. As we meet prophets through the OT narratives, they are introduced as ordinary people. Prophets did not have 'special training' in divination. The exceptions are Jeremiah and Zechariah, seeing that they were priests, and possibly Samuel, for he was brought up in a cultic environment. Nevertheless, prophets were always set apart from the established priesthood. Although one may argue that both priests and prophets conducted prophetism under the influence of the Spirit of the Lord, the performance of the prophets was clearly more spontaneous (charismatic) than that of the cult priests.

In the OT, the distinction between priests and prophets was founded on the authority structures that was described in the Torah (cf. Nm. 17; Nissinen 2010:18; Taggar-Cohen 2011:17). The priestly class usually despised prophets as uneducated and not part of the establishment whilst the OT describes the prophets as people criticising the religious cult and king. The only conduct that priest and prophets had in common was their divine calling to reveal the will of Yahweh and thus influence their society.

From the argument above, it can be deduced that the sharp distinction between inductive and non-inductive divination is 
no longer tenable (De Jong 2007:313; De Villiers 2010:359-364; Nissinen 2010:16-18). Presently, scholars prefer to focus on the common goal of both forms of divination, namely to reveal and preach the will of Yahweh (or deity) and by doing so to influence society around them. This common goal in all forms of divinations or prophetism is the basis for a broader approach to defining 'prophecy'. 'Prophetism' would then, as stated above, be defined as the act of communicating the Word of God with the purpose of influencing the cult and/ or the political life of Israel. Through prophetism - whether inductive or non-inductive - the invisible God becomes audible (Waltke 2007:805). Prophetism in general was aimed at guiding the decision-making of the king or ordinary citizens by warning them or advising them according to the will of Yahweh and by applying the tôrâ to their daily conduct.

\section{No prophets needed}

Hill and Walton (2009:505) divide the ministry and function of OT prophets into three main periods:

- Pre-monarchy: The prophet is a mouthpiece-leader addressing the people, for example Moses and Deborah.

- Pre-classical: The prophet is a mouthpiece-adviser addressing the king and his court, for example Nathan and Elijah.

- Classical: The prophet is a mouthpiece-social or spiritual commentator addressing the people, for example Jeremiah.

A few questions arise from this division: Why did Yahweh use the prophets? To reveal his will? But, why use people outside of the established cult? Why use cultic-uneducated non-priests? From what was stated thus far in the article (and in coherence with the OT narrative), one can make the following assumption: Generally, prophets were not needed to speak on behalf of God within Israelite society. It can be derived from the evidence in the OT that the priests were the actual chosen office to conduct prophetism in Israel. Certainly it is possible that much of the textual material in the Pentateuch and in the whole of the Hebrew Bible were compiled, edited and added later. It could even be argued that it was the priests who did all this editing and compiling of the texts (De Bruyn 2013:70-85) and that the texts thus reflect a point of view that favours the priests at the cost of the prophets. Then again it can be asked: Why would the editor-priests leave so much evidence in the texts of the Hebrew Bible which can be used, do indicate that it was their incapability as priests that contributed to the fall of Judah and Northern Israel? It also can be argued that the editing and compiling of texts are also acts of inductive divination (De Bruyn 2013:70-85). It is therefore possible that the priests, who later compiled and edited texts, again took up their prophetic responsibility as it originally should have been and that they acknowledged their failure as prophets in the First Temple Period. The possibility that it were priests who edited the Hebrew Bible also does not explain why fewer and fewer people from outside of the cult acted as prophets during the Second Temple Period. All this makes it necessary to take a fresh look at the role of priests and prophets in Israel.

\section{Before the time of Moses}

The first evidence of the office of priests in Israel is to be found in Exodus. Naturally Israel was then only a fledgling nation. Thus, one may argue that cult-priests did not operate before the exodus from Egypt. Before this time - that is before Yahweh had established a religious cult in Israel through Moses - the relationship between Yahweh and the believers was more intimate and direct. No mediators were necessary. According to the OT narratives, God 'walked' with Adam and Eve (cf. Gn 2-3). God personally told Noah to build a ship (Gen 6:13). He himself called Terah and Abraham (cf. Gen 12). Later again, God himself revealed his will and instructions to Isaac and Jacob. This is also the case in the narrative of Joseph (cf. Gn 37-50). God talked directly to Joseph. If there were prophets during this period, as it is hinted in Genesis 25:22, they would have been part of a bigger ANE culture and not part of the patriarchal religion.

\section{Moses establishes the cult}

For the purpose of this article, Moses is an interesting figure to investigate. In Deuteronomy 18:15, Moses is called a prophet. He spoke on behalf of Yahweh. He taught the Israelites the law of the Lord and instructed them in accordance with the will of God (cf. Ex 18:13-16). However, Moses did not attempt to influence the decisions within his society like an ordinary prophet would do. He went much further by altering the way in which Israel practiced their religion and conducted themselves as a nation. Moses established the cult with all its offerings, priests, the Ark of the Covenant and the tabernacle (later the temple). At this stage, the cult was the medium and the priests were the mediators between Yahweh and his people. However, as stated earlier, the narrative does not once provide information about the establishment of the office of prophets. It was the task of the priests to teach, preach and reveal the will of Yahweh through divination.

It is important to emphasise the fact that, during this time of political and cult change, Moses acted as Yahweh's independent mouthpiece. Although Moses established the cult and sometimes preformed ceremonies himself, he remained independent from the cult as such.

Deuteronomy 13 is an interesting text. It can be argued that the office of prophet is assumed in this text. Indeed, an historical approach as to the compiling and editing of the texts can be used to argue that the text is a later compilation. However, reading the text in itself indicates false prophets that naturally should not have been part of the 'true' cult of Yahweh. Furthermore, this text does not erase the possibility that the priests were originally the ones who had to act as prophets in Israel.

\section{Conquering Canaan - times of turmoil}

The Book of Judges often states that Israel did evil in the eyes of the Lord (cf. Jdg 6:1). Mostly this was because everyone did 'what was right in his or her own eyes' (Ex 3-4). There was no king, and it seems that the priests at 
the time failed to keep the Israelites committed to the law and covenant of Yahweh (cf. Jdg 2:10-15; 1 Sm 2:12-26).

During this time of turmoil and political instability, Yahweh sent prophets to confront his people (cf. Jdg 4:4; 6:8; $1 \mathrm{Sm}$ $2-3)$. Maybe the best-known prophet from this period is Samuel. He was sent by Yahweh, not only to reveal God's will or to deliver the message of Yahweh's punishment on Eli and his sons (cf. 1 Sm 3), but more importantly, Samuel was commissioned to conduct Israel's transition to a monarchy. Just as God used Moses as an independent agent to oversee the exodus and to establish the cult, he used Samuel as a prophet who did not form part of the established cult to establish the monarchy. Samuel anointed Saul and David as kings of Israel (cf. 1 Sm 10, 16).

\section{During the time of kings}

When David established his kingdom, the priests and the royal house became closely integrated. Not only did David reorganise the priests (1 Chr 22-26), but his sons became priests (2 Sm 8:18). This would have made it extremely difficult for the priests to criticise the king. Narratives relating the history of Israel seldom recount incidents where priests prophesised against or criticised the king. The fate of Abiathar is an example of what may befall a priest who is not loyal to the king (cf. 1 Ki 2:26; Taggar-Cohen 2011:19). In my opinion, this is one of the reasons why Yahweh commissioned people who were not part of the established priests to prophesy against the kings and the cult. Instead of revealing God's will and preaching the law, the priests sometimes became corrupt themselves (cf. for example 1 Sm 2:1-14; 2 Ki 16:11-16; Is 28:7; Jr 6:13, 23:11). Often the priests felt more obliged to support the king than to direct their preaching against his reign. Already in the time of David, God sent Nathan, who was not a priest, to criticise the king (2 Sm 12). An exception to this was Jeremiah, who was a priest, but did not hesitate to fulfil his prophetic duty (Jr 1:1-3) as it should have been since he was a priest.

However, more important for this article is the narrative about queen Athaliah and the revolt against her rule as it is described in 2 Kings 11-12 (cf. 2 Chr 23-24). In this narrative, no mention is made of a prophet, and yet, it would be contended that someone did take on a prophetic role in that instance. The narrative states that when Athaliah was in her seventh year of reign over Judah, Jehoiada the (high-)priest took the lead in a revolt against the queen's rule. As priest, Jehoiada proclaimed Joash, son of Ahaziah, king of Judah. Jehoiada anointed and crowned Joash as king and provided him with a copy of the law. Jehoiada also renewed the covenant between Yahweh and the people and took measures to reform the cult.

Thus, parallels can be drawn between the actions of Moses, Samuel and Jehoiada. As mediator between Yahweh and Judah, Jehoiada crowned Joash as king just as Samuel did with Saul. Unfortunately, Jehoiada's influence only lasted until his death (cf. 2 Chr 24:15-17). Afterwards, the king started to 'do what was wrong in the eyes of the Lord'. Again, a priest stepped forward - Zechariah son of Jehoiada. He prophesied against the king and ultimately died. Thereafter, the narrative recounts how the Lord sent other people who prophesied against the succession of kings. From this narrative we can infer that as long as the established priests did their duty by performing the work of God, preaching and teaching the law and thus influencing society through their prophetic role, prophets from outside of the established cult were not required. To clarify further: when the priests actually did what God originally expected of them, namely to prophesy, there was no need at the time for someone from outside of the cult to fulfil such a prophetic role.

Another narrative that needs to be emphasised is the one about king Uzziah, also known as Azariah (cf. 2 Ki 15:1-6; $2 \mathrm{Chr} 26)$. As long as a man called Zechariah was alive (2 Chr 26:5), Uzziah 'did what was right in the eyes of Yahweh'. Later Uzziah became arrogant and sinned against God by conducting an offering in the temple that was forbidden for him as king, seeing that he was not the high priest (cf. 2 Chr 26:16). It is known from research that (proto-)Isaiah fulfilled the role of prophet during the reign of Uzziah (cf. Is 1:1; Redditt 2008:53-60). Yet, it was significant that neither Isaiah nor another prophet criticised the king - it was the priests themselves who did it (cf. 2 Chr 26:17-20).

Whatever the reasons may be, from then onwards we are never again in the OT narratives informed about priests who had the strength to oppose the wrong-doings of the kings or of the priests themselves. No other prophet is mentioned, except Jeremiah of course. The fact that king Ahaz closed down the temple of Yahweh indicates that the priests did not have the moral courage to prophesy against the kings (2 Chr 28:16-27). Repeatedly it became necessary for Yahweh to utilise agents from outside of the established cult to preach the Word of God. Many of these prophets did not only criticise the king and reveal the social injustice in Israel; they also blamed the priests for being corrupt and for not seeking the Lord's guidance (cf. Jr 2:8; Ezk 8).

From this depiction of the history of Israel, it becomes clear that Yahweh employed prophets from outside the priestly orders in times of emergency when the priests failed in their prophetic task.

The question may be asked: What about the 'call narratives' of Isaiah 6, Jeremiah 1 and Ezekiel 2-3? Do these narratives not sanction the role of a prophetic office? Firstly, this article does not claim that there were no prophetic office, but rather that the priests should have been the prophets in Israel. A separate prophetic office became necessary, because the priests failed in their prophetic duty. Secondly, these narratives only indicate the calling of certain individuals to prophesy on behalf of Yahweh. They do not specifically indicate a permanent office of prophets separate from the priests. These narratives rather show how Yahweh called individuals to preach his words at times when the priests failed in their prophetic calling. 


\section{God's voice in exile}

The priest Ezekiel lived in Babylon during the period before and after the fall of Jerusalem in 586 BC (Ezk 1:1-3). During this time, God used Ezekiel as a prophet to preach God's word to the exiles in Babylonia and to prophesy against those Israelites who still resided in Jerusalem. Although in exile, God used the priest Ezekiel as a prophet to reveal and preach the will of Yahweh and, by doing so, to influence society.

Another prophet used by God in the exilic period was Second Isaiah (Redditt 2008:81-101). With the destruction of the temple in Jerusalem and most of the priests in exile, God used people from outside the temple cult to preach his word.

\section{New beginnings - reforming the cult}

When the exiles began to return in $538 \mathrm{BC}$, their situation showed distinct similarities with the time of the exodus from Egypt. There were no temple and no organised priestly orders. The Israelites' cult and political life had to be reestablished. It is therefore no surprise that God again, like with his calling of Moses, used people from outside the cult to conduct prophetism, that is to reveal the will of Yahweh and thereby influence the society at that stage.

The prophet Haggai encouraged the returned exiles to rebuild the temple. He addressed the governor Zerubbabel and the high priest Jeshua directly ( $\mathrm{Hg} \mathrm{1:1-4).} \mathrm{In} \mathrm{this} \mathrm{time} \mathrm{of}$ hardship, the exiles felt it necessary to rebuild their homes, tend to their fields and defend themselves against intruders. Haggai, however, stated that the only way in which the small community of returned exiles would survive, was by rebuilding the temple and by reinstituting the cult (Murphy 2002:64-65).

In similar vein, the prophet Zechariah had a vision of Yahweh cleansing and reinstating the high priest Joshua (Zch 3). In my opinion this is parallel to the narrative of the inauguration of the priests after the exodus (cf. Ex 28-29). Because there was no established cult, Yahweh used Moses as his prophet to institute the priestly office and the tabernacle (later temple) cult. In much the same way, Yahweh used Haggai and Zechariah to urge the returned exiles to re-establish the temple-cult.

Unfortunately, even after the temple had been rebuilt, the priests lacked the necessary discipline and devotion to influence society according to the will of Yahweh and thus truly to fulfil their prophetic role in society. It was the prophet Malachi's task to call to order the priests who had defiled the altar of the Lord, because they were lax in their work and teachings (cf. Ml 1:6-2:9).

It was not until the time of Nehemiah and Ezra that the cult again started to function as a prophetic institution - in the way Yahweh had ordained it originally. There is debate amongst scholars as to dating Nehemiah and Ezra (cf. Murphy 2002:75-77, 82; Arnold \& Beyer 1999:270-271). Although the researcher agrees with Murphy (2002:77), placing Nehemiah (445 BC) before Ezra (398 BC) and Malachi (500-450 BC), the debate does not influence the arguments or conclusions derived at in this article. What is important in this case is that Ezra was not only a priest, but also a scribe. Moreover, it was during his time that the priests started the canonisation of sacred writings and that literal-divination (-prophetism) became more constituted (Neh 8:1, 2, 8; Murphy 2002:83). It is true that this meant that anyone who could read could interpret, as Murphy (2002:83) states. However, it still did not totally diminish the role that the priests played in taking the lead as to how the written scripture should be interpreted and how it influenced the society of their time. The history of Ezra and his reforms demonstrate this situation. Applying the tôrâ in society was indeed a prophetic function (Baker 1999:270). Thus, the reforms of Ezra in accordance with the law of God demonstrate that the priests indeed were still used by Yahweh as his prophets.

In my opinion, the apocalyptical Book of Daniel is a prime example of literal-prophetism. The author attempted to explain all the events from the time of the exile up to the time of Antiochus IV Epiphanus as part of Yahweh's will and plan which is unveiled.

However, it was not until the time of John the Baptist that a prophet in the traditional sense, had any influence in the society of Israel. Perhaps it is interesting to note that John the Baptist was the son of a priest (cf. Lk 1).

Again, it can be deduced from the above that, even in the Second Temple Period, it was still the task of the cult as a whole to conduct prophetism. Only when the priests failed in their prophetic calling Yahweh sent prophets who were independent of the established cult to preach his will and Word.

\section{Conclusion}

From the arguments above and the lack of evidence in the OT, we must warn against assuming the existence of a permanent prophetic office. Such an office would in any case be a duplication of the priestly office. Therefore, one has to conclude that Yahweh originally ordained the priests to be his prophets. This article does not state that there were no prophetic office, but rather that the priests should have been the prophets in Israel. A separate prophetic office became necessary, because the priests failed in their prophetic duty. This conclusion could be based on the following information:

- The OT narratives do not recount the establishment of prophets as they do in the case of the priests.

- It was the prophetic task of the priests to reveal God's will through the cult as a whole. The temple was the meeting place between Yahweh and men, and it was the area where God communicated with his people.

- The priests were supposed to teach, preach and interpret the will of Yahweh for the king and the whole of Israel.

- Some prophets actually were priests as God originally ordained it, for example Jeremiah, Ezekiel and Zechariah. 
- No mention is made of a prophet when the established priests fulfilled a prophetic role in society, as was the case of the revolt against Athaliah.

Yahweh only used people from outside the cult as prophets when he established or re-established the cult or, more importantly, when the priests failed in their prophetic duty.

This does not diminish the importance of the prophets, but rather make them special envoys of Yahweh in times when the religious establishment and institutions need to be rebuked or warned. The prophets sometimes suffered many hardships for their criticism against the king or priests. In their suffering, they gave another dimension to what it truly means to act in the service of the Lord as a diviner and therefore as a priest of God. Priests or anyone in the service of God will sometimes be unpopular and marginalised. To tell people what God's will is can be a hard task.

As stated earlier in this article, the terms prophet, prophecy and prophetism are still employed today to help believers understand their role and task in the modern world. Therefore, according to the OT narrative, the failure of the priests in their prophetic duty is a warning to the modern church. The church must accept her prophetic duty if she wants to be relevant in the modern world, even if it means being unpopular. If the church fails in this, she is doomed to fade away in the pages of history just as the priests of ancient Israel.

In addition, churches that use the terms prophet and priest to describe the office of the minister and the deacons, may have to rethink the working of their church-governing bodies and church councils. In most reformed churches, the governing body of the church is strictly divided between the elders and deacons where ministers form part of the elders. However, this is not the topic of this article. It only shows that, in the modern day the terms prophet and priest are used very differently from their application in the OT.

\section{Acknowledgements Competing interests}

The author declares that he has no financial or personal relationship(s) which may have inappropriately influenced him in writing this article.

\section{References}

Arnold, B.T. \& Beyer, B.E., 1999, Encountering the Old Testament, Baker Books, Michigan.

Baker, D.W., 1999, 'Israel prophets and prophecy', in D.W. Baker \& B.T. Arnold (eds.), The face of Old Testament studies: A survey of contemporary approaches, pp. 266-294, Baker Academic, Michigan.

Calvyn, J., 1992, Institusie van die Christelike godsdiens, vol. 4, vert. H.W. Simpson, Potchefstroom Herald, Potchefstroom.

Carroll, R.P., 1969, 'The Elijah-Elisha sagas: Some remarks on prophetic succession in Ancient Israel', Vetus Testamentum 19, 400-415.

De Bruyn, J.J., 2013, 'And the Word became prophet', Old Testament Essays 26(1), $70-85$.

De Jong, M.J., 2007, Isaiah among the Ancient Near Eastern prophets, Brill, Leiden.

De Villiers, G., 2010, 'The origin of prophetism in the Ancient Near East', HTS Teologiese Studies/Theological Studies 66, 359-364. http://dx.doi.org/10.4102/ hts.v66i1.795

Driver, S.R., 1902, A critical and exegetical commentary on Deuteronomy, T \& T Clark, Edinburgh.

Freedman, D.N. (ed.), 2000, Eerdmans dictionary of the Bible, Me-R, vol. 4, Wm. B. Eerdmans Publishing Co, Cambridge.

Hill, A.E. \& Walton J.H., 2009, A survey of the Old Testament, 3rd ed., Zondervan, Michigan.

Kitz, A.M., 2000, 'The Hebrew terminology of lot casting and its Ancient Near Eastern context', The Catholic Biblical Quarterly 62, 207-214.

Kraus, H.J., 1966, Worship in Israel: A cultic history of the Old Testament., John Knox Press, Richmond, VA.

Lamb, D.T., 2010, 'A prophet instead of you' (1 Kings 19:16): Elijah, Elisha and prophetic succession', in J. Day (ed.), Prophecy and the prophets in Ancient Israel: prophetic succession', in J. Day (ed.), Prophecy and the prophets in Ancient Israel:
Proceedings of the Oxford Old Testament Seminar, pp. 172-187, T \& T Clark, New Proceedi
York.

Lundbom, J.R., 2010, The Hebrew prophets: An introduction, Fortress Press, Minneapolis.

Murphy, F.J., 2002, Early Judaism: The exile to the time of Jesus, Hendrickson Publishers, Massachusetts.

Nicholson, E.W., 1967, Deuteronomy and tradition, Blackwell, Oxford.

Nissinen, M., 2004, 'What is prophecy? An Ancient Near Eastern perspective', in J. Kaltner \& L. Stulman (eds.), Inspired speech: Prophecy in the Ancient Near East: Essays in Honor of Herbert B. Huffmon, pp. 17-37, T \& T Clark, London.

Nissinen, M., 2010, 'Comparing prophetic sources', in J. Day (ed.), Prophecy and the prophets in Ancient Israel: Proceedings of the Oxford Old Testament Seminar, pp. 3-24, T \& T Clark, New York.

Redditt, P.L., 2008, Introduction to the prophets, Eerdmans Publishing Company, Grand Rapids, MI.

Sakenfeld, K.D. (gen. ed.), 2008, The new interpreter's dictionary of the Bible, Abingdon Press, Nashville.

Taggar-Cohen, A., 2011, 'Covenant priesthood: Cross-cultural legal and religious aspects of Biblical and Hittite priesthood', in M. Leuchter \& J.M. Hutton (eds.), Levites and priests in biblical history and tradition, 11-24, SBL, Atlanta.

Thompson, J.A., 1974, Deuteronomy, Tyndale Old Testament Commentary 5, InterVarsity Press, Downers Grove, IL.

Van Groningen, G., 1990, Messianic revelation in the Old Testament, Baker Book House Michigan

Waltke, B.K., 2007, An Old Testament theology, Zondervan, Michigan.

Walton, J.H., 2006, Ancient Near Eastern thought and the Old Testament: Introducing the conceptual world of the Hebrew Bible, Baker Academic, Grand Rapids. 